\title{
Безсимптомне ураження органів-мішеней як додатковий детермінант загального серцево-судинного ризику при артеріальній гіпертензії
}

Устатті представлено аналітичний огляд прогностичної значимості діагностики безсимптомного ураження органівмішеней при артеріальній гіпертензії в контексті детальнішого визначення серцево-судинного ризику. Представлено основні інструментальні та функціональні проби для діагностики субклінічних стадій ураження органів-мішеней при артеріальній гіпертензії та визначено їх прогностичну значущість щодо основних кардіоваскулярних подій.

Ключові слова: артеріальна гіпертензія, безсимптомне ураження органів-мішеней, прогноз, діагностичні підходи, загальний серцево-судинний ризик.

Артеріальна гіпертензія (АГ), незважаючи на певний успіх у вивченні патогенезу, клініки та лікування, залишається одним із поширених прогностично несприятливих серцево-судиннихзахворювань в Україні та світі. В основу діагностичних підходів та вибору тактики терапевтичної стратегії при АГ покладена концепція визначення загального серцево-судинного ризику (ЗССР). Ця концепція основана на тому факті, що лише у невеликої частки осіб із АГ наявний лише підвищений артеріальний тиск (АТ), у більшості виявляють також інші серцево-судинні фактори ризику (ФР). Тому синтропія підвищеного АТ та інших серцево-судинних ФР може бути несприятливим взаємообтяжувальним тандемом, що загалом формує вищий серцево-судинний ризик (ССР), ніж сума його компонентів окремо. Також в осіб з високим ССР тактика антигіпертензивної терапії, а саме початок, інтенсивність і застосування комбінацій лікарських засобів, можуть відрізнятися від такої у пацієнтів групи низького СCP (Volpe M. et al., 2012).

Клінічна практика свідчить про те, що у пацієнтів групи високого ССР досягти контролю АТ важче, і вони частіше потребують поєднання антигіпертензивної медикаментозної терапії з іншими лікарськими засобами, наприклад з активною гіполіпідемічною, дезагрегантною терапією тощо. За допомогою стратифікаційного підходу та оцінки ЗССР у хворих на АГ для отримання максимальної економічної ефективності лікування необхідно враховувати не лише рівні АТ, але й ЗССР

Традиційні основні ФР підсумовуються та формують градації ЗССР при АГ (низький, помірний, високий, дуже високий). До традиційних ФР при АГ відносять такі (Williams B. etal., 2018): чоловіча стать; вік ( $\geqslant 55$ років у чоловіків, $\geqslant 65$ років у жінок); тютюнопаління; рівень загального холестерину >4,9 ммоль/л(190 мг/дл) та/чи холестерину ліпопротеїдів низької щільності >3,0 ммоль/л (115 мг/дл) та/чи холестерину ліпопротеїдів високої щільності <1,0 ммоль/л (40 мг/дл) у чоловіків та <1,2 ммоль/л (46 мг/дл) у жінок та/чи тригліцеридів $>1,7$ ммоль/л (150 мг/дл); рівень глюкози у плазмі крові натще 5,66,9 ммоль/л (102-125 мг/дл); порушення толерантності до глюкози; ожиріння (індекс маси тіла (IMT) $\geqslant 30$ кг/M²); абдомінальне ожиріння (окружність талії $\geqslant 102$ см у чоловіків, $\geqslant 88$ см у жінок) (для осіб європейської національності); сімейнийанамнез ранніх серцево-судинних захворювань (<55 років у чоловіків, <65 років у жінок).

Проте, якщо традиційні фактори ЗССР при АГ упевнено увійшли у практичну складову лікарської практики, безсимптомне (субклінічне) ураження органів-мішеней залишається недостатньо діагностованим. Визначення безсимптомного ураження органів-мішеней $€$ важливим підтвердженням додаткового ризику, який підвищується з кожним субклінічним порушенням (Perrone-Filardi P. et al., 2017). Пов'язаніз АГ безсимптомні зміни в кількох органах свідчать про прогресування серцево-судинного континууму, а це значно підвищує ризик вище того рівня, який підрахований лише за традиційними ФР, без урахування безсимптомного ураження органів-мішеней.
3 діагностичної точки зору під час початкового обстеження хворого на АГ необхідно: 1) підтвердити діагноз первинної чи вторинної АГ; 2) оцінити ССР, ураження органів-мішеней; 3) на основі стратифікації ризику вибрати лікувальну стратегію АГ. Для цього необхідно виміряти АТ, зібрати медичний анамнез, провести фізикальне, лабораторне та інструментальне обстеження, виявити безсимптомне ураження органів-мішеней.

Тому головна мета цього огляду Настанови Європейського товариства з артеріальної гіпертензії/Європейського товариства кардіологів (ESC/ESH) 2018 р. з лікування артеріальної гіпертензії (Williams B. et al., 2018) - детальна характеристика діагностики та значущості визначення субклінічних уражень при АГ та їх впливу напідвищення градацій ЗССР, що можезумовити змінудіагностичних і терапевтичних підходів у конкретного пацієнта.

Визначним аргументом за доцільність виявлення ураження органів-мішеней уповсякденній клінічній практиціє той факт, що кожен із чотирьох маркерів органного ураження (мікроальбумінурія, підвищення швидкості пульсової хвилі (ШПХ), гіпертрофія лівого шлуночка (ГЛШ) і бляшки в сонних артеріях) $є$ незалежним предиктором серцево-судинної смертності (Williams B. et al., 2018) (табл. 1).

Таблиця 1. Безсимптомне ураження органів-мішеней Пульсовий тиск (у осіб похилого та старечого віку) $\geqslant 60$ мм рт. ст. Електрокардіографічні (ЕКГ)-ознаки ГЛШ (індекс Соколова - Лайона $>3,5$ мВ $\operatorname{RaVL}>1,1$ мB, індекс Корнелла $>244$ мв · мс) або індекс маси ЛШ (МЛШ)

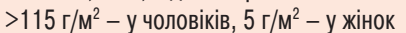

Потовщення стінки сонних артерій (комплекс інтима - медіа (KIM) >0,9 мм) або бляшка

Швидкість каротидно-феморальної пульсової хвилі (ШКФПХ) >10 м/с

Плечо-гомілковий індекс (ПГІ) <0,9

Хронічна хвороба нирок (ХХН) з розрахунковою швидкістю клубочкової фільтрації (рШКФ) 30-60 мл/хв/1,73 м²

Мікроальбумінурія (30-300 мг/добу) або співвідношення альбуміну до креатиніну 30-300 мг/г (3,4-34 мг/ммоль), переважно у вранішній порції сечі

У зв'язкуз важливістю безсимптомного ураження органів-мішеней як проміжного етапу серцево-судинного континууму та детермінанти ЗССР необхідно ретельно виявляти ознаки ураження органів, використовуючи відповідні методики дослідження структурно-функціональних змін основних органів-мішеней: серця, кровоносних судин, нирок, головного мозку, очного дна.

Для діагностики безсимптомного ураження серця при АГ використовують ЕКГ та ехокардіографію (ехоКГ) з тканинною допплерометрією.

ЕКГ у 12 відведеннях повинна бути частиною рутинного обстеження всіх хворих на АГ. Реєстрація ЕКГ має значення як мінімум у пацієнтів віком $>55$ років. За допомогою ЕКГ можна виявити осіб з ознаками ГЛШ (є незалежним предиктором серцево-судинних подій), перевантаження лівого шлуночка (ЛШ), безсимптомних ішемічних епізодів, порушень провідності, дилатації лівого перед- 
сердя (ЛП) й аритмією (в тому числі фібриляцією передсердь (ФП)) Добове моніторування ЕКГ заХолтером показане припідозрі на аритмію та можливі епізоди ішемії міокарда. Окрему увагу приділяють ранній діагностиці ФП як поширеній причині серцево-судинних ускладнень, особливо інсульту, у хворих на АГ, тому раннє виявлення ФП могло би сприяти профілактиці інсульту за рахунок застосування антикоагулянтної терапії з метою запобігання серцево-судинним ускладненням.

ЕхоКГ з технічної точки зору не позбавлена певних труднощів, але ця інструментальна методика чутливіша, ніж ЕКГ, у діагностиці ГЛШ і допомагає уточнити серцево-судинний і нирковий ризик. ЕхоКГ дозволяє точніше стратифікувати загальний ризик і вибрати схему лікування. Адекватне дослідження ЛШ у хворих на АГ містить вимір товщини задньої стінки ЛШ, міжшлуночкової перегородки, кінцевого діастолічного розміру ЛШ. Визначення індексу МЛШ з поправкою на розміри тіла дозволяє виявити ГЛШ, а розрахунок відносної товщини стінки чи співвідношення товщини стінки до радіуса характеризує геометрію шлуночка (концентрична чи ексцентрична гіпертрофія).

АГ супроводжується порушенням процесів розслаблення та наповнення ЛШ (діастолічна дисфункція). Спричинена АГ діастолічна дисфункція, асоційована з концентричною гіпертрофієюі сама по соб може індукувати появу симптомів та ознак серцевої недостатності (CH), навіть при все ще нормальній фракції викиду (ФВ) ЛШ (CH зі збереженою ФВ ЛШ). Наявність діастолічної дисфункції можна встановити лише за допомогою допплерографії при оцінці характеристик трансмітрального кровотоку, якідопомагають кількісно оцінити порушення наповнення та прогнозувати подальший розвиток $\mathrm{CH}$ й загальну смертність. ЕхоКГ слідпоєднувати з пульсовою тканинною допплерографією мітрального кровотоку. Длягіпертонічного ураження серця типове зниження ранньої швидкості діастолічного наповнення (e'), визначене методом тканинної допплерографії. Найчастіше септальна е' знижена більшою мірою порівняно з латеральною е'. Діагностикай визначення вираженості діастолічної дисфункції засновані на показнику е' (середнє з показників у септальній і латеральній частині мітрального отвору) і додаткових вимірах, включаючи відношення трансмітрального Е до е'(співвідношення E/e') і розмір ЛП. Показники швидкості е' і відношення Е/e' більшою мірою залежать від віку й трохи меншою - від статі. За відношенням Е/e' можна виявити підвищення тискунаповнення ЛШ. Прогностичне значення швидкості $\mathrm{e}^{\prime}<8$ у хворих на АГ загальновизнане, а відношення $\mathrm{E} / \mathrm{e}^{\prime}>13$ асоційоване у хворих на АГ з підвищенням ССР, незалежно від МЛШ і відносної товщини стінки ЛШ. Виявлення дилатації ЛП дає додаткову інформацію іє необхідною передумовою для діагностики діастолічної дисфункції. Розмір ЛП найкраще оцінювати за його індексованим об'ємом, значення якого $>34$ мл/ $\mathrm{M}^{2} €$ незалежним предиктором смерті, СН, ФП та ішемічного інсульту.

Діапазони нормальних значень і критерії діагностики гіпертонічного ураження серця за ехоКГ-показниками представлені в табл. 2.

Таблиця 2. Параметри, що використовують для оцінки ремоделювання ЛШ та діастолічної функції у хворих на АГ

\begin{tabular}{|c|c|}
\hline \multirow{2}{*}{$\begin{array}{ll} & \text { Показник } \\
\text { Індекс МЛШ }\left(г / \mathrm{M}^{2}\right) & \end{array}$} & Відхилення від норми \\
\hline & Жінки >95 \\
\hline Відносна товщина стінки ЛШ & $>0,42$ \\
\hline \multicolumn{2}{|l|}{ Діастолічна функція: } \\
\hline - септальна швидкість е' (см/с) & $<8$ \\
\hline • латеральна швидкість е' (см/с) & $<10$ \\
\hline • об'ємний індекс ЛП (мл/м²) & $\geqslant 34$ \\
\hline Тиск наповнення ЛШ: & \\
\hline - середнє відношення Е/e' & $\geqslant 13$ \\
\hline
\end{tabular}

Для діагностики безсимптомного ураження кровоносних судин використовують ультразвукове допплерометричне дослідження з визначенням структурно-функціональних параметрів сонних артерій, швидкості пульсової хвилі, ПГІ.

Ультразвукове дослідження сонних артерій з виміром товщини КІМ і оцінкою наявності бляшокдозволяє прогнозувати інсульт та інфаркт міокарда, незалежно від традиційних серцево-судинних ФР. КІМ вимірюють на рівні біфуркації сонної артерії (що відображає переважно атеросклероз) і загальної сонної артерії (що відображає переважно судинну гіпертрофію). КІМ сонної артерії >0,9 мм розглядається як критерій безсимптомного ураження сонних артерій і відображає процеси патологічного ремоделювання судин при АГ.
Про наявність бляшки свідчить КIM >1,5 мм або локальне збільшення товщини на 0,5 мм, або на 50\% порівняно зі значенням КIM у прилеглих ділянках сонної артерії. Атеросклеротична бляшка є валідним незалежним предиктором серцево-судинних подій.

Феномен жорсткості великих артерій і відбиття пульсової хвилі - найважливіші патофізіологічні детермінанти ізольованої систолічної АГ; верифікують зростання пульсового тиску при старінні. ШКФПХ - золотий стандарт виміру аортальної жорсткості. Граничне значення ШКФПХ до 10 м/с розглядають як показник жорсткості великих артерій. Аортальна жорсткість має незалежну прогностичну значущість відносно фатальних і нефатальних серцево-судинних подій ухворихна АГ. У низці досліджень кількісно оцінено значення ШКФПХ на додаток до традиційних ФР, включаючи SCORE і Фремінгемський бал ризику. За результатами виміру жорсткості артерій значна частка хворих групи середнього ризику може бути рекласифікована до груп вищого або нижчого ССР.

ПГІ може бути допомогою допплерометру з безперервною хвилею та сфігмоманометру для виміру АТ. Низький ПГІ $(<0,9)$ свідчить про ураження периферичних артерій і виражений атеросклероз загалом і $є$ предиктором серцево-судинних подій та асоційований приблизно з дворазовим підвищенням серцево-судинної смертності й частоти основних коронарних подій порівняно із загальними показниками в кожній категорії ризику. Крім того, у проспективних дослідженнях встановлено, що навіть безсимптомне ураження периферичних артерій, діагностоване за низьким ПГІ у чоловіків, супроводжується підвищенням на $20 \%$ серцевосудинної захворюваності та смертності в найближчі 10 років.

Діагностика безсимптомного ураження нирок при АГ ґрунтується на виявленні зниженої функції нирок та/чи підвищеної екскреції альбуміну з сечею. XXН класифікують залежно від рШКФ, яку розраховують за скороченою формулою MDRD (Modification of Diet in Renal Disease), формулою Кокрофта - Голта або формулою CKD-EPI, для чого потрібно знати вік, стать, расу та рівень креатиніну у плазмі крові. При рШКФ $<60$ мл/хв/1,73 м² виділяють три стадії XXН: 3-тю стадію при ШКФ 30-60 мл/хв/1,73 м² та 4-ту і 5-ту стадії - при ШКФ <30 та 15 мл/хв/1,73 м² відповідно. Ці формули допомагають виявити легкий ступінь порушення функції нирок, коли показники креатиніну ще залишаються в межах норми.

Підвищення концентрації креатиніну в плазмі крові або зниження рШКФ свідчать про погіршення функції нирок. Підвищення екскреції з сечею альбуміну чи білка вказує на ураження фільтраційного бар'єра клубочків. Доведено, що мікроальбумінурія служить предиктором розвитку діабетичної нефропатії, у той час як протеїнурія свідчить про вже сформоване ураження паренхіми нирок. Показано, що у хворих на АГ з цукровим діабетом і без нього мікроальбумінурія, що навіть не перевищує звичайнихграничних значень, $€$ предиктором серцево-судинних подій (Clase C.M. et al., 2017). Як у загальній популяції, так і у хворих на цукровий діабет одночасне підвищення екскреції білка з сечею та зниження рШКФ вказують на вищий ризик серцево-судинних і ниркових подій, ніж кожна аномалія окремо. Таким чином, ці ФРє незалежними та кумулятивними. Граничне значення мікроальбумінурії вибрано на рівні 30300 мг/г. Виявлення порушеної функції нирок у хворого на АГ, що виражається вищенаведеними порушеннями, становить дуже потужний і частий предиктор майбутньої серцево-судинної захворюваності та смертності, тому розраховувати ШКФ і визначати мікроальбумінурію рекомендовано в усіх хворих на АГ.

Діагностика безсимптомної ретинопатії при АГ відносно ЗССР має різний прогностичний потенціал, в основу якого покладено ступені (тяжкості) ураження очного дна.

Так, ретинопатія III ступеня (крововиливи в сітківку, мікроаневризми, тверді ексудати, м'які, або «ватяні», ексудати) i IV ступеня (симптоми III ступеня та набряк соска зорового нерва і/або макулярний набряк) указує на тяжку гіпертонічну ретинопатію, яка $є$ сильним предиктором смертності. Зміни І ступеня (фокальне чи розповсюджене звуження артеріол) i Il ступеня (симптом артеріовенозного перехреста) свідчать про ранню стадію гіпертонічної ретинопатії; їі прогностичнезначення для серцево-судинної смертностів ціломуменше.

Зв'язок між калібром судин сітківки й майбутніми інсультами проаналізовано в систематичному огляді й метааналізі: розширення венул сітківки було предиктором інсульту, у той час як калібр артеріол сітківки не був асоційований з інсультом (Sairenchi T. et al., 2011). Звуження артеріол і венул сітківки, які зміни капілярів в інших 
відділах судинного русла, можуть бути ранніми структурними порушеннями при АГ. У цей час вивчаються нові підходи до оцінки співвідношення «стінка - просвіт» артеріол сітківки, які допомагають безпосередньо виміряти ступінь судинного ремоделювання на ранніх і пізніх стадіях АГ.

АГ є валідним фактором клінічно маніфестного інсульту, але також супроводжується ризиком безсимптомного ураження головного мозку, яке виявляють лише при проведенні магнітнорезонансної томографії (МРТ) головного мозку, особливо в осіб літнього та старечого віку. Найтиповішими проявами ураження мозку є вогнища підвищеної інтенсивності в білій речовині, які виявляють майже в усіх хворих на АГ літнього віку, хоча й на різних рівнях, а також приховані інфаркти, більшість з яких мають невеликі розміри й містяться у глибоких відділах мозку (лакунарні інфаркти). Частота таких інфарктів варіює в межах 10-30\%. Нещодавно ідентифіковані вогнища іншого типу, які становлять мікрокрововиливи й виявляються у $\approx 5 \%$ пацієнтів. Наявність гіперінтенсивних вогнищ у білій речовині та прихованих мозкових інфарктів супроводжується підвищенням ризику інсульту, когнітивнихпорушеньі деменції. МРТ, виконане пацієнтам із АГ без явних серцево-судинних захворювань, показало, що приховані цереброваскулярні вогнища мають місце навіть частіше, ніж субклінічне ураження серця та нирок (44; 21 та 26\% відповідно), і нерідко виявляються за відсутності ознак ураження інших органів (Tsoi K.K. et al., 2015). Недостатня доступність і висока вартість не дозволяють широко застосовувати МРТ для обстеження хворих на АГ літнього віку. Однак в усіх хворих на АГ з неврологічними порушеннями й зокрема погіршенням пам'яті, слід шукати гіперінтенсивні вогнища в білій речовині й приховані мозкові інфаркти. Оскільки когнітивні порушення в літньому та старечому віці принаймні почасти пов'язані з АГ, у ході клінічного обстеження хворого на АГ літнього та старечого віку слід застосовувати відповідні тести для оцінки когнітивних функцій.

Таким чином, з метою виявлення безсимптомного ураження органів-мішеней при АГ доцільно проводити обстеження таких органів (Williams B. et al., 2018):

\section{Серце}

- ЕКГ рекомендована всім пацієнтів із АГ для виявлення ГлШ, дилатації ЛП, аритмії або супутніх захворювань серця (рівень доказовості В);

- усім хворим з анамнезом або даними фізикального обстеження, що вказують на значущі порушення ритму, доцільно виконувати тривале моніторування ЕКГ, а при підозрі на аритмію під час фізичного навантаження - ЕКГ-тести з фізичним навантаженням (рівень доказовості С);

- ехоКГ доцільно виконувати для уточнення ССР й підтвердження ЕКГ-діагнозуГЛШ, дилатаціїЛПабо прогнозованих захворювань серця (за наявності підозри на них) (рівень доказовості В);

- в усіх випадках, коли анамнез змушує припускати ішемію міокарда, рекомендується проведення ЕКГ-тестів із фізичним навантаженням, при позитивному чи сумнівному результаті рекомендується проводити стрес-тести (стрес-ехоКГ, стрес-МРТ або стрес-радіоізотопну сцинтиграфію серця) (рівень доказовості C).

Артерії

- Ультразвукове сканування доцільне для виявлення гіпертрофії судин або безсимптомного атеросклерозу, особливо у хворих літнього та старечого віку (рівень доказовості В);

- вимір ШКФПХ доцільний для виявлення жорсткості великих артерій (рівень доказовості В);

- для діагностики ураження периферичних артерій доцільно визначити ПГІ (рівень доказовості В).

Нирки

- Усім хворим на АГ рекомендується визначати рівень креатиніну в плазмі крові й розраховувати ШКФ (рівень доказовості В);

- усім хворим на АГ рекомендується визначати протеїнурію (за тест-смужкою) (рівень доказовості В);

- рекомендується визначати мікроальбумінурію та їі співвідношення з екскрецією креатиніну з сечею (у плямі сечі) (рівень доказовості В).

\section{Огляд очного дна (фундоскопія)}

- Дослідження сітківки доцільно проводити ухворихна тяжко контрольовану чи резистентну АГ для виявлення крововиливів, ексудатів і набряку сосків зорового нерва (рівень доказовості В);
- дослідження сітківки не рекомендується хворим із м'якою та помірною АГ за відсутності цукрового діабету, за винятком пацієнтів молодого віку (рівень доказовості С).

\section{Головний мозок}

- УхворихнаАГз когнітивними порушеннямиможебутидоцільним проведення МРТ або комп'ютерної томографії головного мозку для виявлення прихованих мозкових інфарктів, лакунарних інфарктів, мікрокрововиливів і вогнищ у білій речовині (рівень доказовості С).

\section{Список використаної літератури}

Clase C.M., Barzilay J., Gao P. et al. (2017) Acute change in glomerular filtration rate with inhibition of the renin-angiotensin system does not predict subsequent renal and cardiovascular outcomes. Kidney Int., 91(3): 683-690.

Perrone-Filardi P., Coca A., Galderisi M. et al. (2017) Non-invasive cardiovascular imaging for evaluating subclinical target organ damage in hypertensive patients: A consensus paper from the European Association of Cardiovascular Imaging (EACVI), the European Society of Cardiology Council on Hypertension, and the European Society of Hypertension (ESH). Eur. Heart J. Cardiovasc. Imaging, 18(9): 945-960.

Sairenchi T., Iso H., Yamagishi K. et al. (2011) Mild retinopathy is a risk factor for cardiovascular mortality in Japanese with and without hypertension: the Ibaraki Prefectural Health Study. Circulation, 124(23): 2502-2511.

Tsoi K.K., Chan J.Y., Hirai H.W. et al. (2015) Cognitive tests to detect dementia: a systematic review and meta-analysis. JAMA Intern. Med., 175: 1450-1458.

Volpe M., Battistoni A., Tocci G. et al. (2012) Cardiovascular risk assessment beyond systemic coronary risk estimation: a role for organ damage markers. J. Hypertens., 30: 1056-1064.

Williams B., Mancia G., Spiering W. et al.; ESC Scientific Document Group (2018) 2018 ESC/ESH Guidelines for the management of arterial hypertension. Eur. Heart J., 39(33): 3021-3104.

\section{Бессимптомное поражение органов-мишеней как дополнительный детерминант общего сердечно- сосудистого риска при артериальной гипертензии}

\section{Т.В. Ащеулова, Т.Н. Амбросова}

Резюме. В статье представлен аналитический обзор прогностической значимости диагностики бессимптомногопоражения органов-мишеней при артериальной гипертензии в контексте более детального определения сердечно-сосудистого риска. Представлены основные инструментальные и функциональные пробы длядиагностики субклинических стадий поражения органов-мишеней при артериальной гипертензии и определена ихпрогностическая значимость для основныхкардиоваскулярных событий

Ключевые слова: артериальная гипертензия, бессимптомное поражение органов-мишеней, прогноз, диагностические подходы, общий сердечно-сосудистый риск.

\section{Asymptomatic target-organs damage as additional determinant of global cardiovascular risk in arterial hypertension \\ T.V. Ashcheulova, T.N. Ambrosova}

Summary. An analytical review about prognostic significance of asymptomatic target-organs damage diagnostics in arterial hypertension in context of more detailed assessment of cardiovascular risk is presented in the article. The main instrumental and functional tests for the diagnostics of the subclinical stages of the target-organs damage in arterial hypertension are presented and their prognostic significance for the global cardiovascular events is determined.

Key words: arterial hypertension, asymptomatic target-organs damage, prognosis, diagnostic approach, global cardiovascular risk.

\section{Адреса для листування:}

Амбросова Тетяна Миколаївна

61022, Харків, просп. Леніна, 4

Харківський національний медичний університет,

кафедра пропедевтики внутрішньої медицини №1

E-mail: ambrosovatm@gmail.com

Одержано 14.11 .2018 